\title{
Design of glass/phenolic ballistic composites by implementation of factorial experimental design
}

The purpose of the study is to assess the applicability of full factorial experimental design in predicting the ballistic strength of glass fiber/phenolic ballistic composites. In the study we used a number of ballistic composites $(20 \mathrm{~cm} \times 20 \mathrm{~cm})$ with different thickness and fiber/resin ratio. The composites were made by an open mold high pressure, high-temperature compression of prepreg layers made of plain woven glass fiber fabric and polyvinyl butyral modified phenolic resin.

The preparation of the composite experimental samples was done in accordance to $2^{2}$ full factorial experimental design. The areal weight of composites is taken to be the first factor and the second - fiber/resin ratio. The first factor low and high levels are $2 \mathrm{~kg} / \mathrm{m}^{2}$ and $9 \mathrm{~kg} / \mathrm{m}^{2}$, respectfully and for the second factor - 80/20 and 50/50, respectfully. We used the first-order linear model with interaction to approximate the response i.e. the ballistic strength of the composites within the study domain $(2-9) \mathrm{kg} / \mathrm{m}^{2} \times(80 / 20$ - 50/50) fiber/resin ratio. The influence of each individual factor to the response function is established, as well as the influence of the interaction of the two factors. We found out that the estimated first-degree regression equation with interaction gives a very good approximation of the experimental results of the ballistic strength of composites within the study domain.

Keywords: glass fiber, ballistic, factorial design, regression equation, V50.

\section{INTRODUCTION}

Most military casualties which are due to high speed ballistic projectiles are not caused by bullets. The main threat is from fragmenting devices. In combat, this means, in particular, grenades, mortars, artillery shells, mines, and improvised explosive devices (IEDs) used by terrorists. The main cause of injury to civilians (including police officers) has been bullets [1,2]. These can be classed as 'low velocity' bullets fired from hand guns (revolvers, pistols) at close range. 'High velocity' weapons, such as rifles and machine guns tend to be used at longer ranges. Generally speaking, the velocity itself is less important than the kinetic energy, bullet shape, or composition of the bullet.

The ever increasing needs for safety and security are driving the demand for armor solutions capable of countering present and future threats. But optimal protection needs to be achieved without compromising practical constraints such as weight and cost reductions.

Ballistic protection involves arresting the flight of projectiles in as short a distance as possible. This requires the use of high modulus textile fibres that is those having very high strength and low elasticity. The low elasticity prevents indentation of the body and subsequent bruising and trauma caused by the protective pack after impact. Woven textiles are by far the most commonly used form, although unidirectional tapes and nonwovens are taking ground at great rate [3].

Author's address: Faculty of Technology, University "Goce Delčev", Štip, Macedonia

Received for Publication: 12. 12. 2013.

Accepted for Publication: 25. 02. 2014.
Special grade ballistic glass-fiber's high elongation at break, high modulus and high strength make it the ideal reinforcement solution for reducing weight and for combating increasing threats along with low cost. Specialty glass-fibres meet the Class B strength requirement of military specification MIL-DTL-64154B with a fibre strength of no less than $2758 \mathrm{MPa}$.

Very high strength of glass fibers is essential factor in the energy absorbing mechanism needed to defeat dynamic ballistic impact or to mitigate blast. This makes ballistic glass fibers the material of choice for:

- Infrastructure protection

- Blast panels that protect against land mines

- Engineered ballistics panels (either stand-alone or as part of a combined solution)

Because of the higher weight, compared to other ballistic fibers (nylon, aramid, UHMWPE) glass fibers have limited application for ballistic items or composites for personal protection but they are best cost effective solution for protective infrastructure construction and ground military vehicles.

By combining fibres with an appropriate resin matrix system - typically phenolic - essential mechanical and physical properties can be engineered into the composite.

\section{EXPERIMENTAL PROCEDURE}

For the purpose of the study the experimental composite plates were made by impregnation of glass fiber fabric with thermosetting phenolic resin modified with polyvinyl butyral. Intrinsically brittle 
phenolic resin is modified for flexibility which better contributes to kinetic energy absorption of the highand low velocity bullets as well as fragment impact and its dispersion in the adjacent layers. As reinforcement plain woven glass fiber fabric was used with areal weight of $320 \mathrm{~g} / \mathrm{m}^{2}$, finished with phenolic resin compatible silane coupling agent. The composites i.e. laminates were produced by open-mold compression at high pressure and temperature of $155^{\circ} \mathrm{C}$ within 150 minutes for fully curing i.e. cross-linking of the resin. No post-curing treatment was done.

During the impregnation several factors were observed (speed of impregnation, resin viscosity, metering rolls gap in the impregnating machine) so that the required resin pick-up and its content in the prepreg was achieved. The areal weight (thickness) of the composites was adjusted simply by adding more prepreg layers in the press pack from the lowest to the highest area weight in accordance to the experimental design.

In the $2^{2}$ full factorial experimental design (FFED) we have used in this study, the areal weight of the composite is taken to be the first factor, and the second factor is - fiber/resin ratio. For the first factor the low and the high levels are 2 $\mathrm{kg} / \mathrm{m}^{2}$ and $9 \mathrm{~kg} / \mathrm{m}^{2}$, respectfully, and for the second factor $-80 / 20$ and $50 / 50$, respectfully. Within this relatively narrow areal weight region linear dependence of ballistic strength vs. areal weight was assumed. With that assumption we have taken the first-order linear model with interactions to predict the response function i.e. the ballistic strength of the composites within the stated study domain $(2-9) \mathrm{kg} / \mathrm{m}^{2} \times(80 / 20-50 / 50)$ fiber/resin ratio. Glass/phenolic composites were taken in this study because of the price favorability compared to high-performance fiber composites.

The full factorial experimental design allows to make mathematical modeling of the investigated process in a study domain in the vicinity of a chosen experimental point $[4,5]$. To cover the whole study domain we have chosen the central points of both ranges to be experimental points. For the areal weight of the composites, we have chosen the experimental point to be $5,5 \mathrm{~kg} / \mathrm{m}^{2}$, and for the resin content, the experimental point $35 \%$ (which corresponds to previously defined levels for fiber/resin ratios).

All test are done with a standard $1.1 \mathrm{~g}$ chiselnosed, fragment simulating projectile which is nondeformable, made of quenched and tempered steel with a flat rectangular tip. Figure 1 shows the ballistic test setup.

The ballistic limit velocities, V50, are calculated in accordance to NATO standard STANAG 2920 calculation method [6]. V50 property presents $50 \%$ probability of penetration i.e. of non-penetration of the projectile into the target and is a statistical measure developed by the US military.

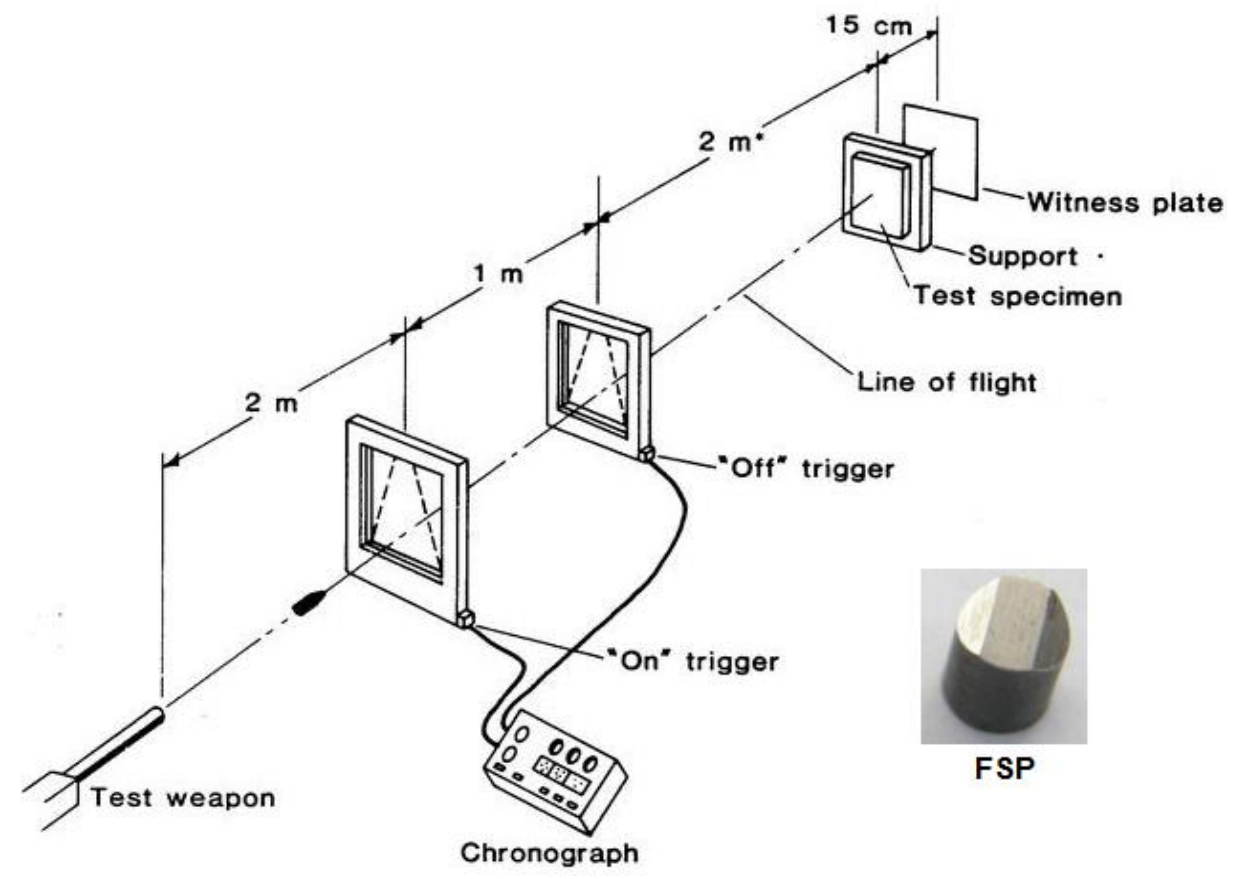

Figure 1 - Ballistic test setup

In accordance to the FFED procedure $4\left(2^{2}\right)$ trails are needed, i.e. all possible combinations of the variables are tested.
The coding of the variables is done in accordance to Table 1. 
Table 1 - Coding convention of the variables

\begin{tabular}{|l|c|c|}
\hline & $\begin{array}{c}\text { Areal weight, } \\
\mathbf{k g} / \mathbf{m}^{\mathbf{2}}\end{array}$ & $\begin{array}{c}\text { Resin } \\
\text { content, } \%\end{array}$ \\
\hline Zero level, $x_{i}=0$ & 5.5 & 35 \\
\hline Interval of variation & 3.5 & 15 \\
\hline High level, $x_{i}=+1$ & 9 & 50 \\
\hline Low level, $x_{i}=-1$ & 2 & 20 \\
\hline Code & $x_{1}$ & $x_{2}$ \\
\hline
\end{tabular}

\section{RESULTS AND DISCUSSION}

The test results are presented in Table 2 together with the experimental matrix.

Table 2 - Experimental matrix with results

\begin{tabular}{|c|c|c|c|c|}
\hline \multirow{2}{*}{ Trials } & $x_{1}$ & $x_{2}$ & $x_{1} x_{2}$ & $\begin{array}{c}\text { Glass } \\
\text { composite }\end{array}$ \\
\cline { 5 - 6 } & & & & V50, $(\mathrm{m} / \mathrm{s})$ \\
\hline 1 & -1 & -1 & +1 & 188.4 \\
\hline 2 & 1 & -1 & -1 & 395.6 \\
\hline 3 & -1 & 1 & -1 & 169.4 \\
\hline 4 & 1 & 1 & +1 & 336.2 \\
\hline-1 Level & $2 \mathrm{~kg} / \mathrm{m}^{2}$ & $20 \%$ & - & - \\
\hline+1 Level & $9 \mathrm{~kg} / \mathrm{m}^{2}$ & $50 \%$ & - & - \\
\hline
\end{tabular}

By implementing $2^{2}$ full factorial experimental design we have found out that response function in coded variables, $y_{k}$, is:

$y_{k}=272.4+93.5 x_{1}-19.5 x_{2}-10.1 x_{1} x_{2}$ and in engineering or natural variables, $y_{n}$ :

$$
\begin{aligned}
& y_{n}=134,1714+33,4476 x_{1}- \\
& -0,2486 x_{2}-0.1924 x_{1} x_{2}
\end{aligned}
$$

In the FFED the term $x_{1} x_{2}$ is the interaction between factors which also might have influence on the response, in our case V50 value.

Analyzing the regression equation it can be found out that the main positive contribution to the V50 is given by the areal weight of the composites i.e. V50 is directly proportional to the areal weight of the composites. On the other hand, the resin content of the composite has inversely proportional effect on ballistic strength which means, the higher the resin content, the lower the ballistic strength. The interaction of the two factors, with coefficient of - 0.1924, has slightly negative effect on the ballistic strength which is of secondary order compared to the influence of areal weight and resin content.

To validate the implementation of the FFED in the study and the assumed model, theoretically calculated results are compared with experimental values for composites with areal weight of $2,3,4$, $5,6,7,8$ and $9 \mathrm{~kg} / \mathrm{m}^{2}$ and fixed resin content of $35 \%$.

This comparison can be done with any other value for the resin content as long as it is within the study domain. The results are presented in Figure 2.

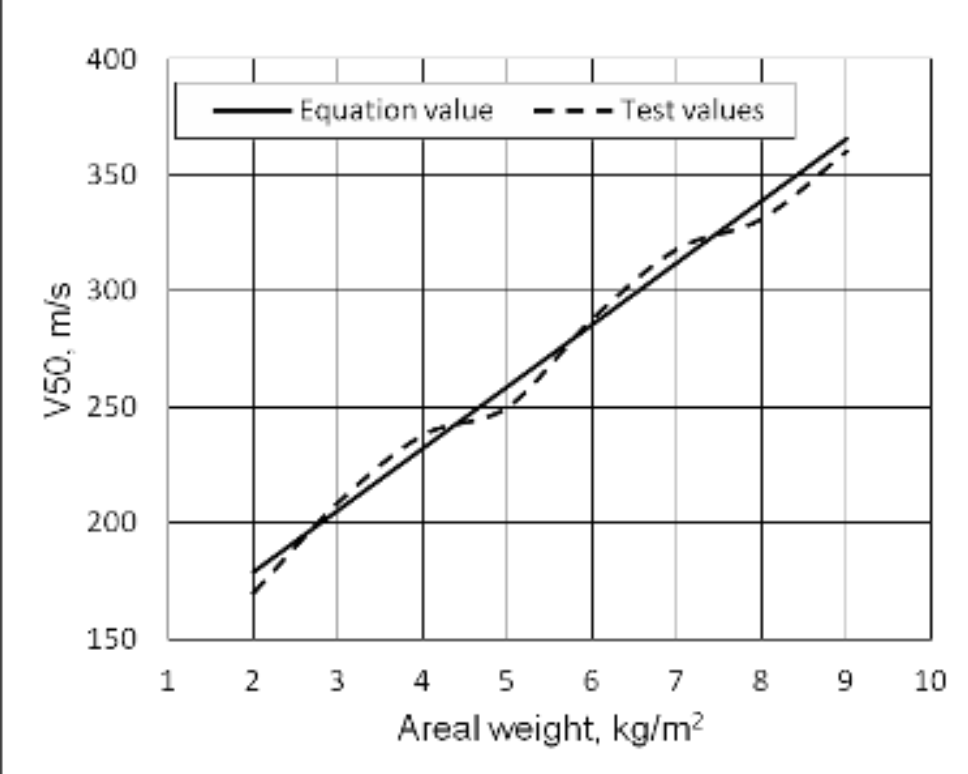

Figure 2 - Theoretical vs. experimental (dashed line) values

As it can be seen from Figure 1 there is a good agreement between calculated and experimental values. All calculated values are placed in a straight line which is in accordance to the assumed model of the experiment and are in close proximity of the experimental data.
How do we design the composites using the regression equation?

- For a given request for the ballistic strength, by substitution of $y_{n}$, in the equation (2), the areal weight of the composites can be calculated and 
then the appropriate number of prepreg sheets used in fabrication of the composites

- For a given weight limit ( $x_{1}$ factor) $y_{n}$ i.e. value of $\mathrm{V} 50$, can be calculated.

In both above cases the resin content $\left(x_{2}\right.$ factor) has to be fixed at $20 \%$ for the most favorable outcome.

\section{CONCLUSION}

Although, generally, over a wide range of areal weight, the ballistic strength is not a linear function of the areal weight [7-10], if the study domain is precisely established (narrow enough), $2^{2}$ full factorial experimental design can be employed to give good approximation of the response i.e. V50 value.

\section{REFERENCES}

[1] Edwin Thomas, Opportunities in protection materials science and technology for future army application, National Academy Press, 2011.

[2] D.C. Prevorsek and H.B. Chin, "Development of a Light Weight Spectra Helmet," Phase I Interim Technical Report from AlliedSignal Inc. to U.S. Army Natick RD\&E Center, Natick, MA, DAAK60-87-C0089/D, 1988

[3] J.G. Donovan, B. Kirkwood, and F. Figucia, "Development of Lower Cost Ballistic Protection," Technical Report Natick/TR-85/019L, U.S. Army Natick RD\&E Center, Natick, MA, 2008

[4] Box, G.E.; Hunter, J.S., Hunter,W.G. (2005). Statistics for Experimenters: Design, Innovation, and Discovery, 2nd Edition. Wiley

[5] D. Dimeski, V. Srebrenkoska, Dizajn i analiza na eksperimenti, University of Stip, Tehnolosko-tehnicki fakultet, 2012.
[6] Nato Standardization Agency, STANAG 2920Ballistic test method for personal armor materials and combat clothing, edition 31 July 2003

[7] L.C. Lin, A. Bhatnagar, and H.W. Chang, Ballistic Energy Absorption of Composites, Proceedings of the 22nd SAMPE International Technical Conference, Nov 6-8, 1990 (Boston, MA), 1990, p 1-13

[8] T.S. Thomas, Facets of a Lightweight Armor System Design, Proceedings of the 22nd SAMPE International Technical Conference, Nov 6-8, 1990 (Boston, MA), 1990, p 304-318

[9] J.W. Song and G.T. Egglestone, Investigation of the PVB/PF Ratios on the Crosslinking and Ballistic Properties in Glass and Aramid Fiber Laminate Systems, Proceedings of the 19th SAMPE International Technical Conference, Oct 13-15, 1987, p 108-119

[10] J.C. Smith, J.M. Blandford, and H.F. Schiefer (1960) Stress-Strain Relationships in Yarns Subjected to Rapid Impact Loading: Part VI. Velocities of Strain Waves Resulting from Impact, Text. Res. J., 30(10), p 752

[11] J.C. Smith, J.M. Blandford, and K.M. Towne, StressStrain Relationships in Yarns Subjected to Rapid Impact Loading: Part VIII. Shock Waves, Limiting Breaking Velocities, and Critical Velocities, Text. Res.

[12] Kumar KS, Bhat TB. Response of composite laminates on the impact of high velocity projectiles. Key Eng Mater 1998;141:337-348.

[13] Wen HM. (2001) Penetration and perforation of thick FRP laminates.Compos Sci Technol 61(8),11631172.

[14] Naik NK, Shrirao P, Reddy BCK. (2005) Ballistic impact behaviour of woven fabric composites: parametric studies. Mater Sci Eng A 412,104-116.

[15] Naik NK, Shrirao P. (2004) Composite structures under ballistic impact.Compos Struct 66,579-590.

[16] Jenq ST, Jing HS, Chung C. (1994) Predicting the ballistic limit for plain woven glass/epoxy composite laminate. Int J Impact Eng 15,451-464.

\section{IZVOD}

\section{DIZAJN STAKLO/FENOLNIH BALISTČKIH KOMPOZITA PRIMENOM FAKTORNOG PLANA EKSPERIMENTA}

Cilj istraživanja je proceniti aplikativnost punog faktornog dizajna eksperimenata u predviđanju balističke ćvrstoće staklena vlakna/fenolna smola balističkih kompozita. U eksperimentu je korišćeno više kompozita $(20 \mathrm{~cm}$ x $20 \mathrm{~cm})$ sa različnom debljinom i različnim odnosom vlakna/smola. Kompoziti su izrađeni u otvorenom kalupu presovanjem slojeva preprega na visokoj temperaturi. Prepreg je na bazi staklene tkanine platnenog prepletaja i fenolne smole modifikovane polivinil butiralom.

Priprema uzoraka je bila u skladu $2^{2}$ punog faktornog dizajna eksperimenata. Površinska masa kompozita je uzeta kao prvi faktot, a drugi - odnos vlakna/smola. Donje i gornje nivo prvog faktora su $2 \mathrm{~kg} / \mathrm{m}^{2}$ and $9 \mathrm{~kg} / \mathrm{m}^{2}$, a drugog - 80/20 i 50/50. Koristili smo linerni model prvog reda sa interakcijom da bi aproksimirali odziv t.j. balističku čvrstoću kompozita u istraživačkom domenu (2 - 9) $\mathrm{kg} / \mathrm{m}^{2}$ x (80/20 - 50/50). Određen je uticaj svakog pojedinačnog faktora na funkciju odziva kao i uticaj interakcije među faktorima. Nadjeno je da proračunska regresiona jednačina prvog reda sa interakcijom daje veoma dobro predviđanje eksperimentalnih rezultata balističke čvrstoće kompozita u istraživačkom domenu.

Ključne reči: stakleno vlakno, balistički kompoziti, faktorni plan, regresiona jednačina, V50.

Originalni naučni rad

Primljeno za publikovanje: 12. 12. 2013.

Prihvaćeno za publikovanje: 25. 02. 2014. 